\title{
Gender: A Filter of Information among University Students?
}

\author{
Dra. Miriam Aparicio \\ National Council of Scientific Research (CONICET). Argentina. \\ E-mail: miriamapar@yahoo.com
}

\section{Doi:10.5901/mjss.2013.v4n11p92}

\section{Abstract}

This study test hypotheses inserted in the psycho-socio-communicational paradigm which long term cognitive effects of the media and the role of the recipient as a subject with his own psychological and socio-cultural characteristics. It is the hypotheses of "agenda-setting". The aim is to analyze the role played by such characteristics and, especially, by gender when it comes to "filtering" information that increases quantitatively, yet is qualitatively unified. Quantitative / qualitative techniques are included. The sample was taken from University graduates. Results related to media impact and differential interpretation existing a high level of education- show non significant statistical differences for this variable, becoming especially relevant under the light of Cognitive Psychology, Media Psychology and Gender Psychology.

Keywords: Gender, Higher Education, Psychology

\section{The Primary Aims}

a) to elucidate such effects on young public which has attained the highest educational level,

b) to detect levels of manipulation and homogenization of "mental maps",

c) to analyze which variables prove decisive as "filters" of the information which increases in quantity and is directed more and more at increasingly segmented audiences,

d) to observe the specific role of gender in what concerns referential interpretation,

e) to recognize possible modifications in performances, attributions and perceptions taking into account the different socio-cultural and pedagogic-institutional insertion.

\section{Hypothesis}

The central hypotheses are offered (agenda-setting) talking into account that forty nine of these were considered:

a) there seems to be marked correlation between the order of importance assigned to the information by the media and that adopted by the youths, which would reflect a high incidence in the emerging "cognitive construing" and the respective mental homogenization,

b) the information does not seem to affect all the subjects in the same way, because of the mediation of intervening factors (education, psychology, etc.);

c) development of the cognitive processes and their products, attributions knowledge appropriation and interpretation of reality would show to be highly dependent on institutional settings;

d) a gender divided reading would reflect the influence of cultural-historical construing, still present in underdeveloped, discriminatory contexts;

e) this interpretation would be closer between males and females belonging to the same academic institutions which are thought to be, by some theories, strong homogenizing factors.

\section{Method}

\subsection{Sample}

The sample was made up of graduates ( $\mathrm{N}=516)$ from eighteeen careers in Cuyo University (Argentina) between 1980 and 1993. The sampling was stratified. Confidence interval was set at $95 \%$ and error margin at $4 \%$. 


\subsection{Instruments}

- Quanti-qualitative techniques were complemented, statistical analysis on products and psychosocial ones on processes.

- Among the first, a semistructured survey that included 151 variables (base line, psychosocial, personality, institutional, structural and communicational ones) was used.

- The latter included in-depth interviews (in life-story contexts), anecdote accounts and non-obstructive observation.

- Of the wide spectre of variable, gender, psychological and communicational variables (agenda-setting) were central here.

\subsection{Procedure}

1. Survey of data in files the cover more than a decade.

2. Implementation of the aforementioned technique in the home.

3. Survey of the two agendas (the media and public ones) and establishment of the time frame, taking into account the models of the agenda-effect: awareness, relevance and priorities (Becker, McCoombs, Mc Leod). Graphic media was employed (six representative national newspapers, of different "ideology"), as well as visual media (television newwreels).

4. The comparison procedures for both agendas and the analytical strategy are original.

\section{Results}

In reference to the hypothesis results corroborate:

a) presence of the "agenda-effect", though in a differential manner according to the socio-educational level and other factors,

b) the irrelevance of the "gender" factor in relation with selective and priority assimilation of reality.

\subsection{Agenda-effect}

- It was observed that the agenda-effect is present even in the most educated subjects: only what the media offers is thought about; the rest of the information is neither internalized nor are the subjects aware of it, it does not constitute a part of the "mental maps".

- Thus, a certain homogenization of thought is formed, as the result of the quantitative homogenization of the news and current production routines.

- The similarity of interpretations of all subjects -male and female- shows the extent of the media's power concerning uniformity of the contents of thought.

- Nevertheless, the strengthening of a certain image of reality is neither samely nor always present in all subjects, depending on the intervening psycho-socio-cultural values.

\subsection{Relations between differential interpretation and educational level}

- Education featured as a decisive filter: interpretation is less similar to that of the media agenda and of more critical nature -whether in males or females- the higher the educational level.

\subsection{Relationship between differential interpretation and the homogenizing role of organizations}

- The educational institution emerges, corroborating what was theorized, as a second great filter: the interpretation of males and females belonging to the same educational institution had much more in common than those proceeding from different academic units.

- It also follows that: a) the importance of the socio-cultural an ideological-institutional insertions in the creation of cognitive mechanisms and behavioral strategies at the individual level; b) the obvious incidence that different institutional mediations can effect on the subject / world relationship; c) given the effectiveness of 
these mediations, the contribution or risk derived from the idiosyncrasy of the institutional frame.

\subsection{Relationship differential interpretation / gender relations}

- Gender, in high educational levels, did not appear as a filter, against what expected up to a short time ago. Manner of seeing, accepting, judging or internalizing reality were very much alike in female and male subjects, to the point of not recognizing any statistically significant differences in any case.

\section{Conclusions}

- The final result of the cognitive process is similar in males and females at highly educated levels.

- Female psychology (culturally conceived as predominantly emotional and less skillful) does not result in a distorted interpretation of reality.

- Such findings are relevant for Cognitive Psychology, Media Psychology and, especially, for Gender Psychology.

\section{References}

Aparicio, M. (1997). Sobre efectos de los media: una investigación sobre hipótesis de la agenda-setting. Investigaciones en Sociología, 6, 35-58.

Aparicio, M. (2001). ¿Qué transformaciones se operan en los públicos a partir de la imagen de sociedad que hoy ofertan los medios? Un análisis desde la psicología social de la comunicación. Enfoques, 13, 1-2, 41-51.

Becker, L; McCombs, M \& J. McLeod (1975). The Development of Political Cognitions. Political Communication, Beverly Hills: Sage, 2164.

Bregman, D. \& Missika, J. (1987). On framing the campaing: mass media roles in negociating the meaning of the vote. European Journal of Communication, 2.

Bregman, D. \& Missika, R. (1989). La fonction d'agenda: une problématique en devenir. Hermes, 4, 17-24.

Cherkaoui, M. (1979). Les paradoxes de la réussite scolaire. Paris: PUF.

Cobb R. \& Elder, C. (1971). The Politics of Agenda-Building: An Alternative Perspective for Modern Democratic Theory. The Journal of Politics, 33, 897-915.

Cohen, B.C. (1963). The press and Foreign Policy. Princeton: Princeton University Press.

Cook, F., Tyler, T., Goetz, E., Gordon, M., Protess, D., Leff, D. \& Molotch, H. (1983). Media and Agenda-Setting: Effects on the Public, Interest Group Leaders, Policy Makers and Policy. Public Opinion Quaterly, 47, 16-35.

Eco, U. \& Fabbri, P. (1978). Progetto di ricerca sull'utilizzazione dell'informazione ambientale. Problemi dell'informazione, 4, 555-597.

Erbring, L., Goldenberg, E. \& Miller, A. (1980). Front-Page News and Real-World Cues: A New Look at Agenda-Setting by the Media. American Journal of Political Science, 24(1), 16-49.

Escarpit, R. (1976). Théorie générale de l'information et de la communication. Paris: Hachette.

Ettema, J. \& Cline, F. (1977). Deficits, Differences and Ceilings: Contingent Conditions for Understanding the Knowledge Gap. Communication Research, 4, 39-47.

Eyal, C. Winter, J. \& De George, W. (1981). The Concept of Time Frame in Agenda-Setting. Mass Communication Review Yearbook, 2, 212-217.

Gerbner, G. \& Gross, L. (1976). Living with Television: The Violence Profile. Journal of Communication, spring, 18-24.

Hall, S. (1980). Cultural Studies: Two Paradigms. Media, Culture and Society, 2, 57-72.

Hovland, C., Harvey, O. \& Sheriff, M. (1957). Assimilation and Contrast Effects in Reaction to Communication and Attitude Change. Journal of Abnormal and Social Psychology 40 2, 244-252.

Hovland, C. \& Weiss, W. (1949). The Influence of Source Credibility on Communication Effectiveness. Public Opinion Quaterly 15(4), 635-650.

Iyengar, S. (1979). Television News and Issue Salience: A Reexamination of the Agenda-Setting Hypothesis. American Politics Quaterly, 7, 4, 395-416.

Lasswell, H. (1936). Politics: Who Gets What, When, Hhow. New York: McGraw Hill.

Lazarfeld, P. (1941). Remarks on Administrative and Critical Communications Research. Studies in philosophy and social science,9, 1 ,2-16.

Le Bon, G. (1983). Psicología de las masas. Madrid: Morata.

Mancini, P. \& Wolf, M. (1990). Mass Media Research in Italy: Culture and Politics. European Journal of Communication, 5, $28-42$.

Mc Clure, R. \& Patterson, T. (1976). Print vs. Network News. Journal of Communications, 26(2), 23-28.

Mc Combs, E. (1981). Setting the Agenda for the Agenda-Setting Research. An Assessment of the Priority Ideas and Problems. Mass Communication Review Yearbook, 2, 209-211. 
Mc Combs E. \& Shaw, D. (1972). The Agenda-Setting Function of Mass Media. Public Opinion Quaterly, 36, 176-187.

McKuen, M. \& Coombs, S. (1981). More than News. Media Power in Public Affairs. Beverly Hill: Sage.

McLeod, J., Becker, L. \& Byrnes, J. (1974). Another Look at the Agenda-Setting Function of the Press. Communication Research, 1, 2 , 131-166.

Neumann, N. (1973). Returns to the Concept of Powerful Mass Media. Studies of Broadcasting, 9, 67-112.

Neumann, N. (1983). The Effect of Media on Media Effects Research. Journal of Commmunication, 33,3, 157-165.

Pasquier, D. (1994). Vingt ans de recherches sur la télévision. Sociologie du Travail, 34, 63-85.

Patterson, T. (1980). The role of Mass Media in Presidential Campaings: The Lesson of 1976. Items, 2, 25-30.

Rimoldi, H. (1997). Información y cognición e información y creatividad. psicopedagógica, 2 2, 11-27.

Rimoldi, H. (1999b). Información y cognición e información y creatividad. Boletín de la Academia Nacional de Medicina, 40, 10-14.

Shaw, E. (1979). Agenda-Setting and Mass Communication Theory. International Journal for Mass Communication Studies, 25, 2, 96105.

Wolf, M. (1987). La investigación en la comunicación de masas. Buenos Aires: Paidós.

Zucker, H. (1978). The Variable Nature of New Media Influence. Communication Yearbook, 2, 225-240. 